\title{
Impact of the Dental Anatomy Course Trainings on the Psychomotor Skills of Students
}

\section{Diş Anatomisi Dersi Uygulamalarının Öğrencilerin Psikomotor Becerileri Üzerindeki Etkisi}

\author{
Erdal EROĞLU ${ }^{1 *}$ (D), Zeynep BAŞAĞAOĞLU DEMIREKIN ${ }^{1}$ (D), Merve ERKEN ${ }^{1}$ (D)
}

${ }^{1}$ Süleyman Demirel University, Faculty of Dentistry, Department of Prosthodontics, Isparta, Turkey.

\begin{abstract}
A B S T R A C T
Objective: To evaluate the impact of the dental anatomy course on the psychomotor skills of dental students.

Material Methods: The study was carried on 121 volunteer students of the dental anatomy course. The 9-holepeg- test (9-HPT) was used for psychomotor skills assessment at the beginner vs. experienced status (fall vs. spring terms). Test completion time in seconds (sec) was used as primary data. Dominant (DH), and nondominant hand $(\mathrm{N}-\mathrm{DH})$, gender, academic success at the higher education admission test (GPA), and the course's final assessment scores of training were used as variables. Data were analyzed with IBM SPSS V23. Paired samples t-test, the MANOVA test, and Spearman's rho correlation were used for statistical analyses $(\mathrm{p}<0.05)$.
\end{abstract}

Results: The participants' DH scores improved from $20.55 \pm 2.48$ to. $18.32 \pm 1.84 \mathrm{sec}(p \leq 0.001)$, while N-DH scores improved from $22.78 \pm 2.66$ to $20.52 \pm 2.52 \mathrm{sec}$ ( $p \leq 0.001$ ). Female's $\mathrm{DH}$ scores were $20.16 \pm 2.37$ vs. $17.90 \pm 1.59$ sec $(p \leq 0.001)$, the $\mathrm{N}-\mathrm{DH}$ scores were $22.40 \pm 2.48$ vs. $19.83 \pm 1.95 \mathrm{sec}(\mathrm{p} \leq 0.001)$ among the fall and spring terms, respectively; while males' DH scores were $21.30 \pm 2.56$ vs. $19.13 \pm 2.04 \mathrm{sec}(p \leq 0.001)$, and the N-DH scores were $23.52 \pm 2.86$ s vs. $21.88 \pm 2.95 \mathrm{sec}(p=0.003)$. Females' $\mathrm{DH}$ scores were better than males for fall $(p=016)$ and spring $(p \leq 0.001)$ terms, and $\mathrm{N}-\mathrm{DH}$ scores were better for fall $(p=027)$ and spring $(p \leq 0.001)$ terms. Neither GPA nor 9-HPT scores affected the course's end-of-term practical exam notes.

Conclusion: The dental anatomy course significantly contributes to the psychomotor proficiency development of the students.

Keywords: Dentistry, education, dental anatomy course, psychomotor skills.

Alınış / Received: 08.09.2021 Kabul / Accepted: 29.12.2021 Online Yayınlanma / Published Online: 20.12.2021 


\section{Ö Z E T}

Amaç: Diş Anatomisi ve Morfolojisi uygulamalı dersinin öğrencilerin psikomotor beceri gelişimi üzerindeki etkisini değerlendirmek.

Materyal-Metot: Çalışma, uygulamalı bir eğitim içeriği olan Diş Anatomisi ve Morfolojisi dersinde eğitim gören 121 gönüllü öğrencinin katılımı ile gerçekleştirildi. Öğrencilerin başlangıç ve deneyimli durumlarındaki (güz-bahar yarıyılları) psikomotor durum değerlendirmesi için 9-Delikli Çubuk-Testi (9-HPT) uygulandı. Test tamamlama süresi (sn) temel veri seti olarak kullanıldı. Baskın ve baskın olmayan el, cinsiyet, dersin sene sonu pratik not ortalaması ve üniversiteye giriş sıralaması ise değişken olarak değerlendirildi. Veriler, IBM SPSS V23 uygulamasında analiz edildi. İstatistiksel analiz için eşleştirilmiş örnek T-testi, MANOVA testi ve Spearman rho korelasyonu kullanıldı ( $\mathrm{p}<0.05)$.

Bulgular: Başlangıç ve deneyimli dönem ölçümlerine göre katılımcılar baskın el skorlarında $(20,55 \pm 2,48$ / $18,32 \pm 1,84)$ ve baskın olmayan el skorlarında $(22,78 \pm 2,66 / 20,52 \pm 2,52)$ anlamlı bir gelişim gösterdi $(p \leq 0,001)$. Kadın katılımcıların başlangıç ve deneyimli hallerindeki baskın $(20,16 \pm 2,37$ / 17,90 $\pm 1,59)$ ve baskın olmayan $(22,40 \pm 2,48$ vs. $19,83 \pm 1,95)$ el skorları anlamlı bir gelişim gösterdi $(p \leq 0,001)$. Erkek katılımcıların başlangıç ve deneyimli hallerindeki baskın $(21,30 \pm 2,56 / 19,13 \pm 2,04)$ ve baskın olmayan $(23,52 \pm 2,86 / 21,88 \pm 2,95)$ el skorları anlamlı bir gelişim gösterdi $(p=0,003)$. Kadın katılımcılar, baskın el skorlarında başlangıç ve deneyimli hal ölçümlerinde erkek katılımcılara göre daha iyi bir psikomotor beceri gösterdiler $(p=0,016 / p \leq 0,001)$. Dönem sonu pratik not ortalaması ve üniversiteye giriş sıralaması ile psikomotor beceri gelişimi arasında anlamlı bir bağıntı bulunamadı.

Sonuç: Diş Anatomisi ve Morfolojisi dersi uygulamaları öğrencilerin psikomotor beceri gelişimleri üzerinde anlamlı bir katkı sağlamaktadır.

\section{Introduction}

Dentistry is a health field that requires excellent motor skills, improved hand-eye coordination, and spatial perception. These characteristics are defined as primary program outputs and competencies for dentistry schools around the world. Dentists expect to restore lost tooth tissue quickly by using different materials and performing some skills in dental laboratories [1,2].

The dental anatomy course is taught in the initial years of dental schools worldwide as a part of the basic core sciences program. The learning objectives of this pre-clinical course in the dental curriculum are to improve students' cognitive and psychomotor skills related to the morphology and spatial and functional relationships of human dentition and promote these skills to recreate proper tooth form in restorative clinical procedures competently [3-5].

Most faculties of dentistry continue to use traditional teaching methods for this course, based on theoretical and psychomotor skills training components. The theoretical part is generally based on lectures accompanied by two-dimensional visual materials such as slides. The psychomotor skills training part is designed to improve the students' psychomotor skills. Usually, these exercises are based on add-on or cutback techniques completed in wax, gypsum, and soap blocks due to relatively low cost, easy handling, and reproducibility $[1,3]$.

Psychomotor skills terminologically define motor skills, hand skills, and 3D perception. These skills affect individuals' activities related to daily life and have a very significant impact on their professional competence $[6,7]$. They can be measured using various hand skills tests to evaluate individuals' motor 
capacities or disabilities. These tests are often used in physical therapy and rehabilitation centers to evaluate professional development or determine the pre-occupational condition. The most common of these evaluation tests include block carving, tremometer testing, O'Connor Tweezer Dexterity Test, and Purdue Pegboard test. However, there is no consensus on the best from a psychometric perspective [8]. The Nine Hole Peg Test (9-HPT) is a simple, fast, dexterity test with proven validity and reliability [9]. It is susceptible to changes in upper extremity performance [9].

In many dental curricula, initial psychomotor skills development assessment may not be possible until they move on to pre-clinical courses. Evaluation of psychomotor competencies in the early period is essential to increase the clinical success of students [2]. Psychomotor skills tests may help evaluate the practical training part of the course's effect or compare the course success with counterparts in other dentistry programs.

This study aims to measure and evaluate the effects of the psychomotor skills training content of the dental anatomy course on the psychomotor skills of the dental students at Süleyman Demirel University.

Null hypotheses of this study are:

a) The dental anatomy course does not affect students' psychomotor skills,

b) The dominant and non-dominant hand use does not affect psychomotor skills,

c) Gender does not affect psychomotor skills,

d) The academic achievement score in the higher education exam does not affect psychomotor skills,

e) 9-HPT scores of the participants do not correlate with success in the final assessment scores of training.

\section{Material and Method}

\section{Participants}

All the first-year students (135 total) at the Süleyman Demirel University Faculty of Dentistry were interviewed to participate in the study at the beginning of the academic year 2019-2020. The study was conducted in two stages to assess the participants' psychomotor skills improvement: in the first month of the fall term to evaluate the student's beginner status and at the first month of the spring term to evaluate the experienced status. The students were informed about the study and were guaranteed that they would not be advantaged/disadvantaged by accepting/refusing to participate. The Ethics Committee of Süleyman Demirel University Faculty of Medicine approved the study (2018:189), and each participant signed a written consent form according to the World Medical Association's Helsinki Declaration.

The following volunteers were excluded:

- $\quad$ Students who were repeating years and with previous college degrees because of the possibility of having acquired specific skills previously,

- $\quad$ Students who had an injury or disease severe enough to limit the dexterity of both hands,

- $\quad$ Students aged over 25 to homogenize the sample.

A total of 121 participants $(88.32 \%$ of all) (mean age $18.45 \pm 0.75)$ were included in the study. The distribution of participants according to gender was as follows: 80 females (66.12\%) (mean

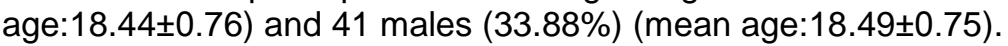

\section{Measurement Tool}

The 9-Hole Peg Test (9-HPT) is a brief, simple, standardized, timed measure of upper extremity function and dexterity (9). 9-HPT material comprises a shallow dish next to the 9-hole pegboard with nine wooden/plastic pegs (Baseline Evaluation Instruments, USA, Lot: 055965) [Figure1]. The pegboard is placed before the subject at midline, with the container holding the pegs oriented towards the participant's hand being tested. Subjects are seated on a height-appropriate chair to ensure that the tabletop is at mid-chest level. The test task requires the subject to take the pegs from a container, one by one, and place them into the holes on the board as quickly as possible. Afterwords, they must remove the pegs from the holes and replace them in the container one by one [Figure2]. The time 
taken to complete the test activity in seconds is recorded as the score. The test begins with the dominant hand. Two consecutive trials with the dominant hand are immediately followed by two consecutive trials with the non-dominant hand. The means of the scores are recorded as the dominant and the non-dominant hand scores.

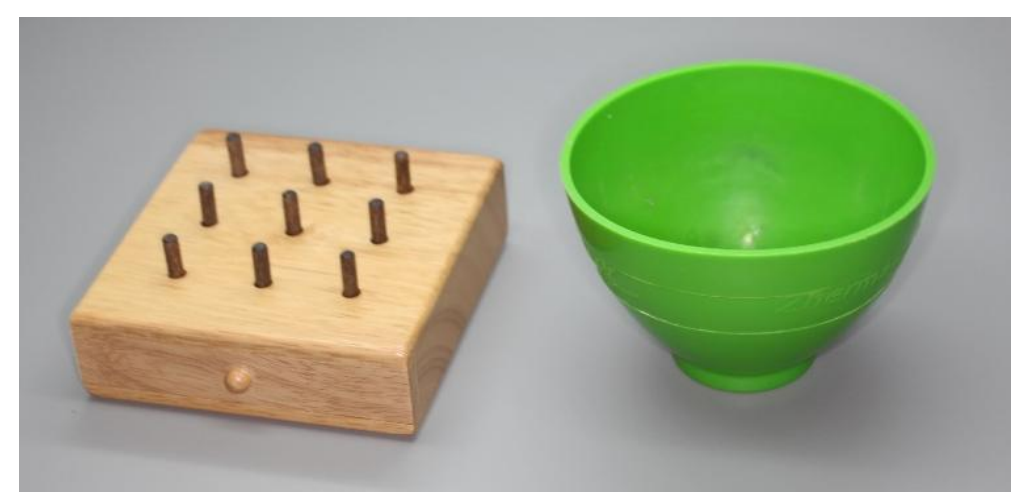

Figure1: 9-HPT test kit

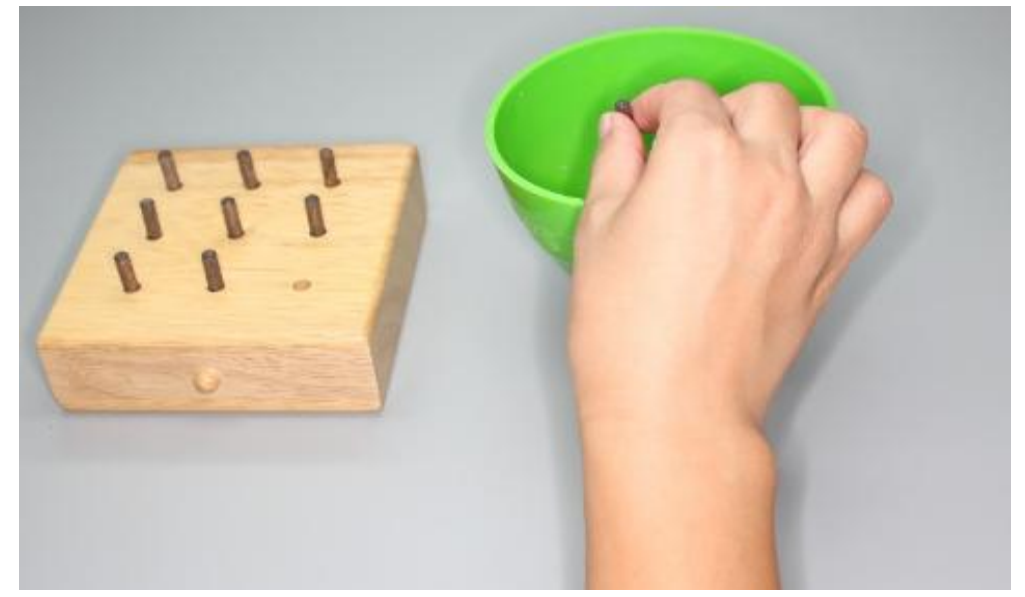

Figüre 2: 9-HPT test

\section{Statistical analysis}

Data were analyzed with IBM SPSS V23. Conformity to normal distribution was evaluated with the Kolmogorov Smirnov test. Paired samples t-test was used to compare the dominant hand and the nondominant hand scores (in seconds) regarding the 9-HPT tests in fall and spring terms. Comparisons by gender were evaluated with independent samples t-test. The MANOVA test was used to examine the fall and spring terms 9-HPT scores according to gender variables. Spearman's rho correlation was used for the relationship between quantitative measurements. The significance level was taken as $\mathrm{p}<0.05$.

\section{Results}

A total of 121 individuals participated ( 80 Female, 41 Male) in the study. The first and second-terms 9 HPT test scores performed by the participants with their dominant / non-dominant hands are shown in Table1. 
Table1: Dental Anatomy course students' dominant and non-dominant hands 9-HPT scores according to gender variation at the fall term and spring term.

\begin{tabular}{|c|c|c|c|}
\hline \multicolumn{2}{|c|}{ Variables } & \multirow{2}{*}{$\begin{array}{l}\text { Fall Term* } \\
20.16 \pm 2.37\end{array}$} & \multirow{2}{*}{$\begin{array}{l}\text { Spring Term } \\
17.90 \pm 1.59\end{array}$} \\
\hline \multirow{3}{*}{ Dominant hand scores } & Female $(n=80)$ & & \\
\hline & Male $(n=41)$ & $21.30 \pm 2.56$ & $19.13 \pm 2.04$ \\
\hline & Total $(n=121)$ & $20.55 \pm 2.48$ & $18.32 \pm 1.84$ \\
\hline \multirow{3}{*}{ Non-dominant hand scores } & Female $(n=80)$ & $22.40 \pm 2.48$ & $19.38 \pm 1.95$ \\
\hline & Male $(n=41)$ & $23.52 \pm 2.86$ & $21.88 \pm 2.95$ \\
\hline & Total $(n=121)$ & $22.78 \pm 2.66$ & $20.52 \pm 2.52$ \\
\hline
\end{tabular}

When the participants' 9-HPT performances were evaluated according to the fall and spring terms variables, the dominant hand mean scores decreased from 20.55 to 18.32 seconds, respectively. The difference among the terms is statistically significant $(p<0.001)$. Likewise, according to the fall and spring terms variables, the non-dominant hand 9-HPT mean scores decreased from 22.78 to 20.52 seconds. The difference is statistically significant $(p<0.001)$. Statistical analysis shows that this result, observed in use for both dominant and non-dominant hands, is statistically significant $(p<0.001)$. These results reject the null hypothesis that the dental anatomy course does not affect students' psychomotor skills.

When the participants' 9-HPT performances were evaluated according to the hand used at the test (dominant vs. non-dominant), the dominant hand and the non-dominant hand 9-HPT mean scores at the fall term were 20.55 and 22.78 seconds, respectively. The difference is statistically significant $(p<0.001)$. The spring term 9-HPT mean scores for the dominant and non-dominant hands were 18.32 and 20.52 seconds, respectively. The difference is statistically significant $(p<0.001)$.

When the participants' 9-HPT performances were evaluated according to gender variable, female participants' dominant hand scores show a statistically significant difference among the fall term and spring term measurements $(p<0.001)$. The mean score decreased from 20.16 to 17.90 seconds. Male participants showed a similar statistically significant difference among the fall term and spring term9HPT measurements, and the mean scores were 21.3 and 19.13 seconds, respectively $(p<0.001)$. The non-dominant hand scores also show statistical significance, according to gender variables. Female participants' fall term and spring term 9-HPT mean scores difference is statistically significant $(p<0.001)$. The mean score decreased from 22.4 to 18.93 seconds. Likewise, male participants' 9 -HPT mean scores decreased from 23.52 to 21.88 seconds, and the difference is statistically significant $(p<0.001)$.

Results show that female participants' fall term 9-HPT measurements for the dominant and nondominant-hand are statistically better than male participants' $(p=0.016$, and $p<0.001$, respectively). Likewise, female participants' spring term 9-HPT measurements for the dominant and non-dominanthand are also statistically better than male participants' $(p=0.027$, and $p<0.001$, respectively).

The participants' 9-HPT performances were also evaluated according to the academic achievement score in the higher education exam. However, the dominant hand, the non-dominant hand, the fall term, spring term measurements, and the final assessment scores of training variables showed no statistically significant relationship.

The statistical relationship between the 9-HPT scores of the participants and their success at the final training assessment scores was also explored. Results exhibited no statistically significant relationship among 9-HPT scores and final assessment scores of training. 


\section{Discussion and Conclusion}

The results of this study rejected the null hypotheses mentioned above.

a) The dental anatomy course does not affect students' psychomotor skills,

b) Gender does not affect psychomotor skills,

c) The dominant and non-dominant hand use does not affect psychomotor skills.

The results of this study accepted the null hypothesis mentioned above;

d) The academic achievement score in the higher education exam does not affect psychomotor skills.

e) The 9-HPT scores of the participants' do not correlate with success in the final assessment scores of training.

Dentistry education is a five-year program in Turkey after high school graduation. The Higher Education Institution determines admission conditions to dentistry faculties. Students who complete their high school education are entitled to enroll in dentistry after a written exam. No interviews or psychomotor tests are performed during or before registration [10]. In the first three years of dentistry education, there are practical courses to improve psychomotor qualifications before dental clinical practices $[11,12]$.

The dental anatomy course is given in the first year of the program, and there is no practical course other than this one [12]. Therefore, it can be said that the results of our study are due to the applications of this course in the academic year 2019-2020 at Süleyman Demirel University Faculty of Dentistry. However, the repetition of this study on first-year students in consecutive years or its application in different faculties of dentistry will be positive for the reliability of these results. There was no study evaluating the outputs of this psychomotor skills training part of the course in the sense of psychomotor proficiency in the literature review.

The Council of Higher Education in Turkey had published a national framework of core competencies in dentistry before graduation and emphasized the importance of motor skills in this program. As in the whole world, dental anatomy is one of the precursor courses taught in dentistry and forms the basis of dental education in Turkey [11,13]. The learning objectives of this course are a) the anatomical and morphological characteristics of permanent and deciduous teeth and b) developing the psychomotor skills of the students to restore the teeth with the appropriate form and function $[11,13]$.

The dental anatomy course at the Süleyman Demirel University Faculty of Dentistry consists of theoretical and psychomotor skills education. The face-to-face course is given two days a week, two theoretical and six practical hours in total (Education year: 2019-2020) [Table2] [12]. The theoretical part consists of traditional lectures. Psychomotor skills training is planned twice a week as schematized in Table2. On the first day, the F2F course's weekly schedule starts with feedback from the previous week. Then, a brief lecture about the next task is followed by a demonstration of the task by the educator, and the students are expected to demonstrate the task by themselves (supported by the educator). On the second day, the students demonstrate the task by themselves. The tasks are evaluated and scored. Feedback about these tasks is also discussed with students in the first lesson of the following week [Figure3] [12].

Table2: Assessment and evaluation of the dental anatomy course at Süleyman Demirel University Faculty of Dentistry

Assessment and evaluation of the dental anatomy course at Süleyman Demirel University Faculty of Dentistry (2019-2020)

\begin{tabular}{|c|c|c|c|c|c|c|c|}
\hline \multicolumn{3}{|c|}{ Fall Term } & \multicolumn{3}{|c|}{ Spring Term } & \multicolumn{2}{|c|}{ End-of-term Exam } \\
\hline $\begin{array}{l}\text { Weekly } \\
\text { practical } \\
\text { task }^{*}\end{array}$ & $\begin{array}{c}\text { Practical } \\
\text { exam }\end{array}$ & $\begin{array}{c}\text { Theoretical } \\
\text { exam }\end{array}$ & $\begin{array}{l}\text { Weekly } \\
\text { practical } \\
\text { task* }\end{array}$ & $\begin{array}{c}\text { Practical } \\
\text { exam }\end{array}$ & $\begin{array}{c}\text { Theoretical } \\
\text { exam }\end{array}$ & $\begin{array}{c}\text { Practical } \\
\text { exam }\end{array}$ & $\begin{array}{c}\text { Theoretical } \\
\text { exam }\end{array}$ \\
\hline$\% 30$ & $\% 30$ & $\% 40$ & $\% 30$ & $\% 30$ & $\% 40$ & $\% 60$ & $\% 40$ \\
\hline
\end{tabular}




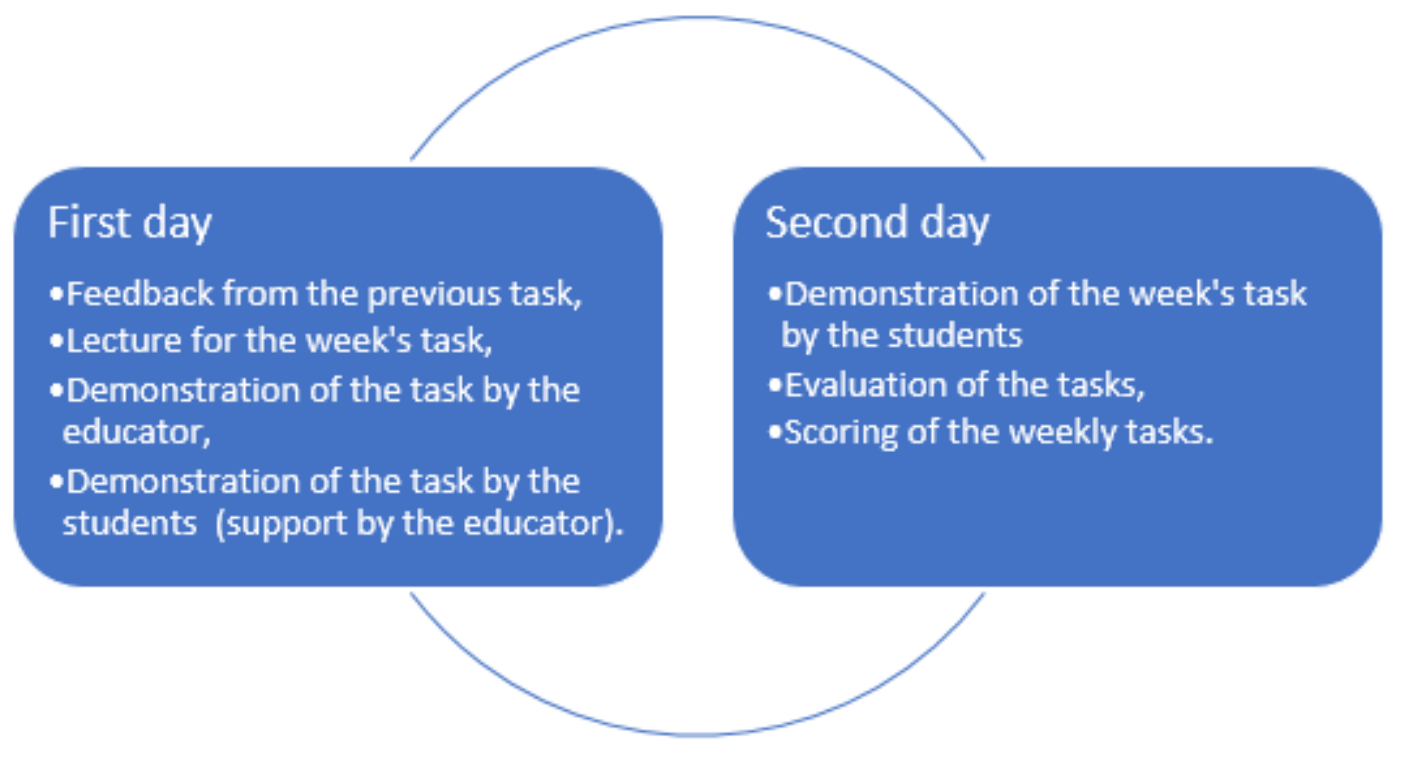

Figüre 3: Dental anatomy course's weekly schedule at Suleyman Demirel University

One of the main problems of dentistry education is determining whether educators can evaluate dentistry students' visual perception and hand skills [14]. The Perceptual Ability Test for admission to some faculties of dentistry is a valid cognitive determinant for the hand skills of candidates. However, there is no verified psychomotor test. Computer-aided simulation training, which has been raised in recent years, is a tool for improving pre-clinical practical training performance and is helpful to the preclinical dentistry curriculum. Emerging Haptic technologies have the potential to enhance the simulation experience [15].

The weak correlation between the tests Gillet and his colleagues used in their study confirms the difficulty in finding a reliable test that can predict the likelihood of the student becoming a good dentist. Variables such as a student's interests or personality can affect the outcome [16].

The evaluation of psychomotor skills of dentistry students has been the subject of numerous studies over time. Researchers wanted to use these tests for several purposes: a) during the admission process to the faculties of dentistry, b) to determine the effect of the practical training parts of the curriculum on psychomotor skills, and c) demonstrate psychomotor skills as professional competence [17-20].

Although the importance of the dental anatomy course on psychomotor skills is known, there is no consensus among the faculties in Turkey on how to conduct the practical component of this course. Among the faculties of dentistry in Turkey, the training hours of the dental anatomy course can vary from four to eight hours a week [21-23]. The possible effects of these differences on psychomotor skills development have not been studied. Psychomotor skills tests can be a guide in this regard. This present study and its results may raise awareness about evaluating the outputs of the dental anatomy course. Research on this subject can set a parameter for the regulation of the curriculum in terms of practical course hours, the way the course is taught, the materials that can be used during the course, and the measurement-evaluation methods.

This study shows that the psychomotor skills training parts of the dental anatomy and morphology course taught at the Süleyman Demirel University significantly improve students' psychomotor proficiency development. Participants showed psychomotor skills progression with both their dominant and non-dominant hands. Gender has been observed as another factor that is effective in this development. Female participants have demonstrated a more successful psychomotor competence with both their dominant and non-dominant hands than males. The academic success required for university admission has not had an impact on psychomotor skills development. No statistical correlation was found between 9-HPT scores and the final assessment scores of training. 


\section{References}

[1] Kellesarian, SV. Flipping the Dental Anatomy Classroom. Dent J (Basel). 2018 Jun 21;6(3):23.

[2] De Azevedo Rde, A.; da Rosa, W.L.; da Silva, A.F.; Correa, M.B.; Torriani, M.A.; Lund, R.G. Comparative effectiveness of dental anatomy carving pedagogy: A systematic review. J. Dent. Educ. 2015, 79, 914-921.

[3] Ales Obrez, Charlotte Briggs, James Buckman, Loren Goldstein, Courtney Lamb, William G Knight. Teaching clinically relevant dental anatomy in the dental curriculum. J Dent Educ. 2011 June;75(6):797-804

[4] Okeson J, Buckman J; Section on Dental Anatomy and Occlusion, American Association of Dental Schools. Curriculum guidelines for dental anatomy. J Dent Educ 1993;57(5):382

[5] De Azevedo, R.A.; Correa, M.B.; Torriani, M.A.; Lund, R.G. Optimizing quality of dental carving by preclinical dental students through anatomy theory reinforcement. Anat. Sci. Educ. 2017.

[6] Wang Y-C, Magasi SR, Bohannon RW, Reuben DB, McCreath HE, Bubela DJ, et al. Assessing dexterity function: a comparison of two alternatives for the NIH Toolbox. Journal of Hand Therapy. 2011;24(4):313-21.

[7] Volman M, van Schendel BM, Jongmans MJ. Handwriting difficulties in primary school children: A search for underlying mechanisms. American Journal of Occupational Therapy. 2006;60(4):451-60.

[8] Lugassy D, Levanon Y, Pilo R, Shelly A, Rosen G, Meirowitz A, et al. Predicting the clinical performance of dental students with a manual dexterity test. PloS one. 2018;13(3):e0193980.

[9] Grice KO, Vogel KA, Le V, Mitchell A, Muniz S, Vollmer MA. Adult norms for a commercially available Nine Hole Peg Test for finger dexterity. American Journal of Occupational Therapy. 2003;57(5):570-3.

[10] Admission requirements for dentistry program. Süleyman Demirel University Faculty of Dentistry (date of access: 02.08.2021). https://obs.sdu.edu.tr/Public/EctsShowProgramDetailsAdmission.aspx

[11] National core education program in dentistry (date of access: 02.08.2021). https://www.yok.gov.tr/Documents/Kurumsal/egitim_ogretim_dairesi/Ulusal-cekirdek-egitimiprogramlari/dis_hekimligi.pdf /

[12] Süleyman Demirel University Faculy of Dentistry program contents (date of access: 02.08.2021). https://obs.sdu.edu.tr/Public/EctsShowProgramDetailsCourseContent.aspx

[13] Süleyman Demirel University Faculy of Dentistry, dental anatomy course lecture form (date of access: 02.08.2021).https://obs.sdu.edu.tr/Public/EctsCourseDetails.aspx?DersNo=210100121160\&BolumNo=0\&BirimNo $=21 \&$ DersBolumKod=DIS121

[14] Giuliani M, Lajolo C, Clemente L, Querqui A, Viotti R, Boari A, et al. Is manual dexterity essential in the selection of dental students? British Dental Journal. 2007;203(3):149.

[15] Urbankova A, Eber M, Engebretson SP. A complex haptic exercise to predict pre-clinical operative dentistry performance: a retrospective study. Journal of dental education. 2013;77(11):1443-50

[16] Gillet D, Quinton A, Jeannel A. Is there a link between writing ability, drawing aptitude and manual skills of dental students? European Journal of Dental Education. 2002;6(2):69-73

[17] Gansky SA, Pitchard H, Kahl E, Mendoza D, Bird W, Miller AJ, Graham D. Reliability and validity of a manual dexterity test to predict preclinical grades. J Dent Educ 2004;68(9):985-94

[18] Kramer GA. Predictive validity of the Dental Admission Test. J Dent Educ 1986;50:526-31.

[19] deAndres AG, Sanchez E, Hidalgo JJ, Diaz MJ. Appraisal of psychomotor skills of dental students at University Complutense of Madrid. Eur J Dent Educ 2004;8(1): 24-30.

[20] Oudshoorn WC. The utility of Canadian DAT Perceptual Ability and Carving Dexterity scores as predictors of psychomotor performance in first-year operative dentistry. J Dent Educ 2003;67(11):1201-8.

[21] Okan University Faculty of Dentistry Syllabus (date of access: 02.08.2021). https://www.okan.edu.tr/uploads/pages/ders-programi-2/dhf-1-sinif-2019-2020-bahar-donemi-ders-programi27012020.pdf

[22] Yeditepe University Faculty of Dentistry Syllabus (date of access: 02.08.2021). https://dishekimligi.yeditepe.edu.tr/tr/dersler/2244 
[23] Bezmialem University Faculty of Dentistry Syllabus (date of access: 02.08.2021). https://bezmialem.edu.tr/dis-hekimligi-fakultesi/tr/Publishinglmages/Sayfalar/lisans-egitimi/lisans-egitimi-dersprogrami/2019-2020-guz-1-Sinif-ders-programi-v2.pdf 